\title{
ATRIBUT RUANG SEBAGAI PENANDA RUANG RITUAL PADA PESAREAN GUNUNG KAWI KABUPATEN MALANG
}

\author{
Dhinda Ayu, Antariksa, Abraham M. Ridjal \\ Jurusan Arsitektur Fakultas Teknik Universitas Brawijaya \\ dhindayu@gmail.com
}

\begin{abstract}
ABSTRAK
Pelaksanaan suatu ritual tidak dapat dipisahkan dengan pelaku, waktu, ruang dan benda-benda yang digunakan dalam proses ritual. Ruang merupakan suatu hal yang memiliki peran sangat penting dalam pelaksanaan ritual. Atribut atau perabot di dalam suatu ruang yang digunakan untuk melaksanakan aktivitas ritual juga memiliki peran dalam pembentukan ruang ritual. Bangunan-bangunan yang dianggap sakral pada Pesarean Gunung Kawi memiliki atribut ruang yang berfungsi membentuk ruang ritual pada pelaksanaan berbagai jenis aktivitas ritual yang ada pada tempat tersebut. Tujuan studi ini adalah untuk mengetahui ruang ritual yang dibentuk oleh atribut ruang pada Pesarean Gunun Kawi. Metode yang digunakan pada penelitian ini adalah metode deskriptif kualiatif. Hasil studi ini menunjukkan bahwa selain sebagai penanda ruang ritual, atribut ruang juga membagi ruang sesuai dengan derajat privasi.
\end{abstract}

Kata kunci: atribut, ruang, ritual

\begin{abstract}
Implementation of a ritual could not separate from its subject, time, space and things that used during the process. Space is a very important thing in the implementation of a ritual. Attribute or furniture inside the space that used to carry out the ritual activity also has a role to build a ritual space. Buildings that are considered sacral at Pesarean Gunung Kawi have space attribute which function to create a ritual space on the implementation of various types of rituals at that place. The purpose of this study is to determine the ritual space that formed by space attribute at Pesarean Gunung Kawi. The method used in this study is qualitative descriptive research. The result of this study showed that beside as a ritual space signage, space attribute also divide the space in accordance with the level of privacy.
\end{abstract}

Keywords: attribute, space, ritual

\section{Pendahuluan}

Suatu kegiatan dapat terwujud apabila ada interaksi antara kegiatan tersebut dengan wadahnya. Hal tersebut menunjukkan bahwa semua aktivitas yang dilakukan oleh manusia tidak dapat dipisahkan dengan penggunaan suatu ruang. Pada suatu ruang yang sama memungkinkan untuk terjadi beberapa aktivitas yang berbeda. Seperti halnya pada Pesarean Gunung Kawi yang memiliki tradisi melakukan banyak aktivitas ritual. Ritual-ritual yang ada pada Pesarean Gunung Kawi dilakukan sebagai peringatan hari-hari penting atau dengan tujuan lain sesuai yang dikehendaki masing-masing peziarah. Setiap ritual memiliki tata cara dan aturan yang berbeda, sehingga akan menimbulkan ruang ritual yang berbeda meskipun dilakukan pada tempat yang sama. 
Hal-hal yang memiliki peran penting dalam pelaksanaan ritual, yakni waktu, benda dan pelaku ritual, serta tempat atau ruang (Koenjtaraningrat, 1990). Penggunaan benda atau peralatan ritual dapat mendukung proses pelaksanaan ritual, seperti bunga, kemenyan, dupa ataupun sesaji yang dianggap dapat mempercepat terkabulnya doa. Selain benda-benda yang dihadirkan oleh para peziarah, benda-benda yang terdapat di dalam maupun luar ruangan juga dapat berfungsi sebagai elemen yang membentuk ruang ritual, baik sebagai fixed, semi fixed maupun non fixed feature (Hall, 1966). Pentingnya unsur benda-benda yang digunakan pada pelaksanaan ritual menunjukkan bahwa arsitektur tidak akan bermakna tanpa terjadinya suatu peristiwa, sementara peristiwa sendiri tidak akan bermakna tanpa adanya pelaku dan simbol-simbol yang berfungsi sebagai pembentuk ruang (Deapati, 2009:71).

\section{Metode Penelitian}

Metode yang digunakan pada penelitian ini adalah metode deskriptif kualitatif. Selanjutnya untuk mengetahui penggunaan ruang ritual dilakukan dengan melakukan pengamatan. Penelitian ini dilakukan di Pesarean Gunung Kawi Kabupaten Malang karena pada tempat tersebut terdapat beberapa aktivitas ritual yang dilakukan pada tempat-tempat yang dianggap sakral. Fokus pada penelitian ini berdasarkan adanya aktivitas ritual pada suatu ruang sangat erat hubungannya dengan atribut ruang sebagai elemen yang memperkuat zonasi dan hirarki ruang. Metode yang digunakan pada penelitian ini adalah metode deskriptif kualitatif. Selanjutnya untuk mengetahui peran atribut ruang pada ruang ritual dilakukan dengan melakukan pengamatan.

\section{Hasil dan Pembahasan}

Pesarean Gunung Kawi merupakan suatu kompleks objek wisata ritual yang terletak di Desa Wonosari, Kabupaten Malang. Terdapat beberapa bangunan sakral dan tempat peribadatan yang dianggap penting oleh masyarakat (Gambar 1). Beberapa aktivitas ritual yang ada pada Pesarean Gunung Kawi dilaksanakan pada tempat tersebut.

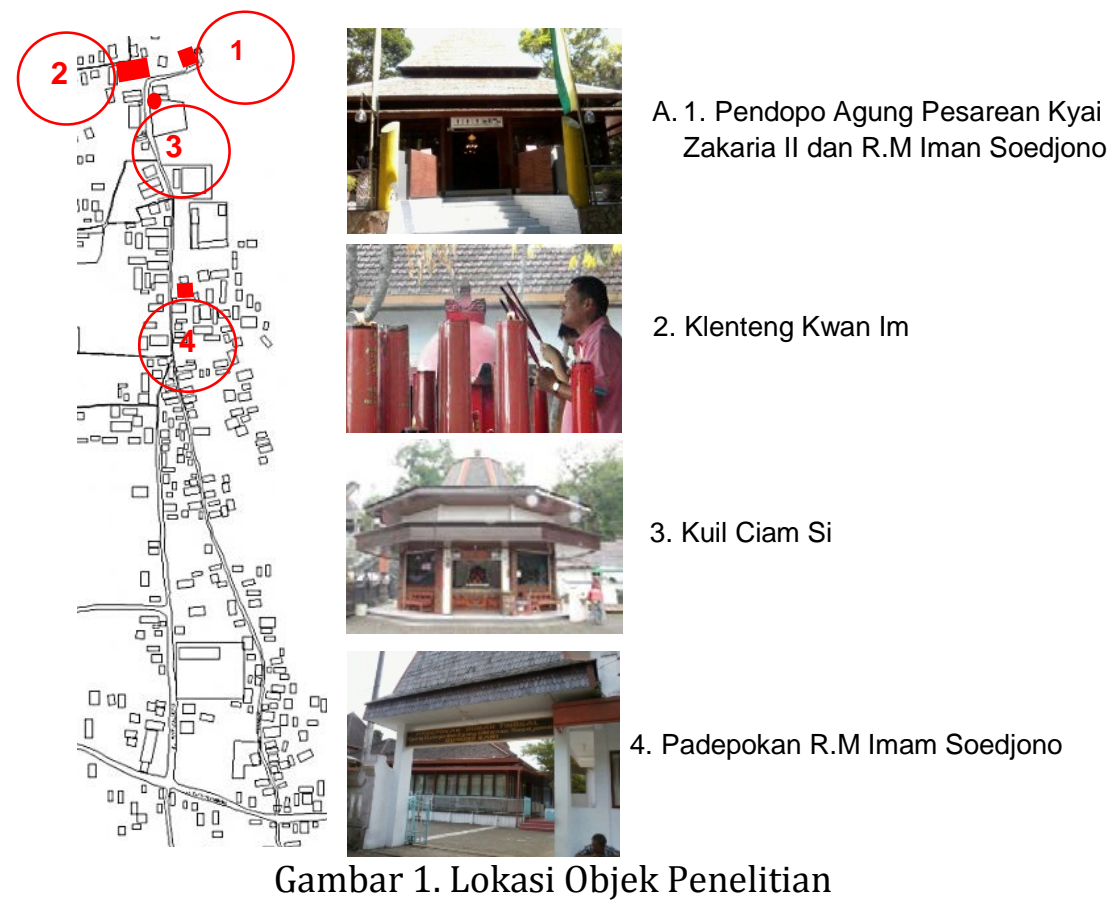




\section{Pendopo Agung}

Pendopo Agung merupakan tempat yang dianggap paling sakral di Pesarean Gunung Kawi karena pada tempat tersebut terdapat dua makam tokoh yang dihormati oleh masyarakat, yakni Eyang Djoego dan R.M Iman Soedjono selain makam kedua tokoh tersebut, pada Pendopo Agung juga terdapat atribut ruang yang berhubungan dengan aktivitas ritual (Gambar 2).

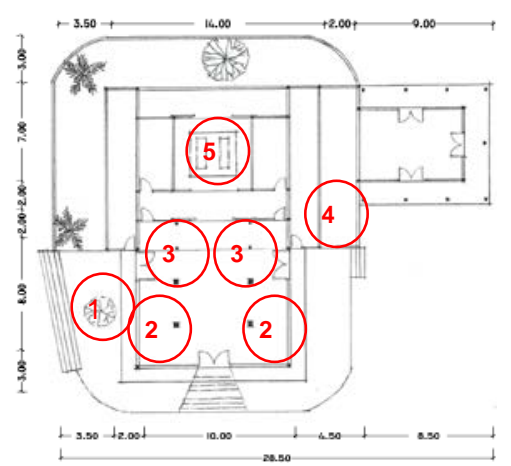

1. Pohon dewandaru

2. Jam

3. Pagar pembatas

4. Dua guci kuno

5. Makam Eyang Djoego dan R.M Iman Soedjono

Gambar 2. Atribut Ruang pada Pendopo Agung

Masing-masing atribut ruang tersebut memiliki fungsi pada setiap aktivitas ritual. Terdapat beberapa atribut yang dianggap sakral oleh masyarakat, seperti pohon Dewandaru, dua buah guci kuno dan makam Eyang Djoego dan R.M Iman Soedjono. Dengan adanya atribut ruang yang bersifat sakral maka ruang tersebut akan juga bersifat sakral. Selain itu, posisi dimana atribut ruang tersebut diletakkan juga dipengaruhi oleh pencapaian dan hirarki ruang terbentuk. Seperti makam yang bersifat privat dan sakral namun memiliki pencapaian langsung dari arah pintu masuk, sehingga diperlukan suatu pembatas yang memperjelas batas antara zona semi publik dan privat (Gambar 3).

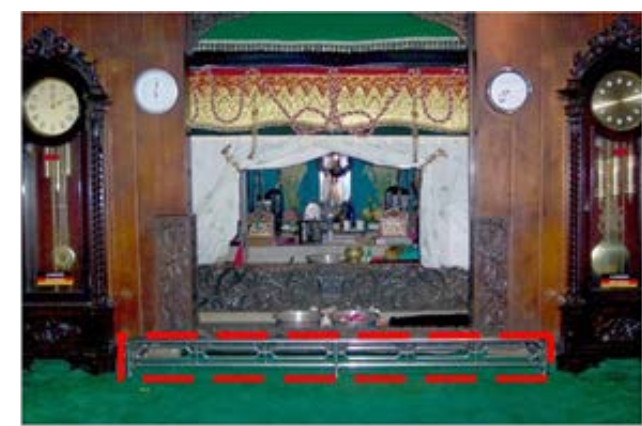

Gambar 3. Atribut Ruang pada Pendopo Agung

Hal tersebut menunjukkan bahwa makam merupakan atribut ruang paling sakral dan ditunjukkan dengan perbedaan level lantai yang semakin tinggi saat mendekati makam (Tjahjono \& Santoso, 2004) (Gambar 4). Selain menunjukkan tingkat kesakralan, perbedaan level lantai juga menunjukkan derajat privasi ruang (Gambar 5).

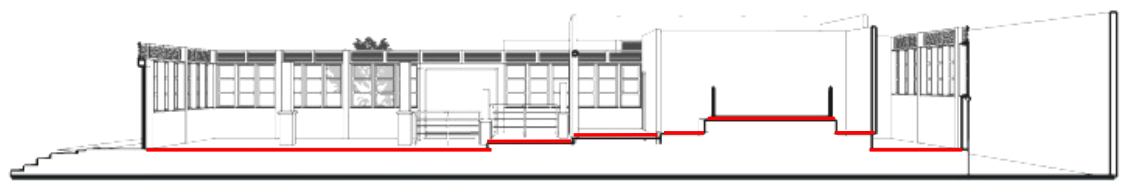

Gambar 4. Ruang Ritual pada Malam Jumat Legi 


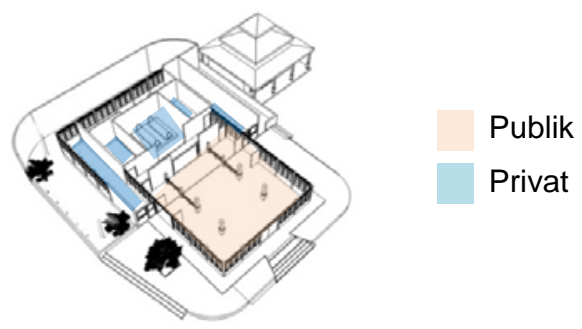

Gambar 5. Pembagian Zona Ruang pada Pendopo Agung Berdasarkan Derajat Privasi

Pada ruang luar, keberadaan pohon Dewandaru sebagai elemen pembentuk ruang memiliki pengaruh yang sangat besar dalam pembentukan ruang ritual. Pohon Dewandaru mengubah sifat ruang publik dari profan menjadi sakral (Gambar 6).

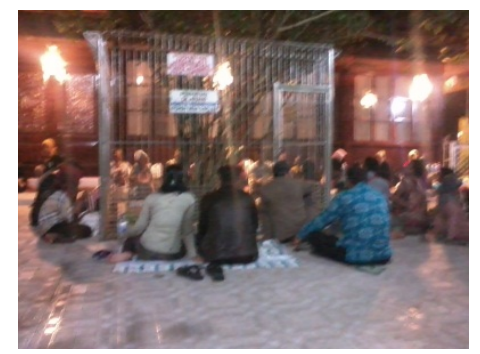

Gambar 6. Ruang Ritual yang Terbentuk di Sekitar Pohon Dewandaru

Masing-masing atribut ruang baik di dalam maupun luar ruangan memiliki fungsi dan peran yang berbeda pada (Tabel 1).

Tabel 1. Peran Atribut Ruang pada Ruang Ritual

\begin{tabular}{|c|c|c|c|}
\hline No & Atribut Ruang & Keterangan & Peran dalam Ruang \\
\hline 1 & $\begin{array}{l}\text { Pohon dewandaru } \\
2 \\
2 \\
3 \\
2\end{array}$ & $\begin{array}{l}\text { Dianggap sebagai pohon } \\
\text { yang dapat memberikan } \\
\text { keberuntungan. }\end{array}$ & $\begin{array}{l}\text { Elemen utama pembentuk ruang ritual pada ruang } \\
\text { publik yang menimbulkan ruang sosial di sekitar } \\
\text { pohon tersebut. }\end{array}$ \\
\hline 2 & Jam & $\begin{array}{l}\text { Merupakan pemberian dari } \\
\text { peziarah yang doanya telah } \\
\text { terkabul. }\end{array}$ & $\begin{array}{l}\text { Untuk menghargai pemberian para peziarah maka } \\
\text { benda ini diletakkan di zona publik, sehingga dapat } \\
\text { memperkuat zona ruang publik pada ruang tengah } \\
\text { Pendopo Agung. }\end{array}$ \\
\hline 3 & Pagar pembatas & $\begin{array}{l}\text { Berfungsi untuk membatasi } \\
\text { ruang yang digunakan } \\
\text { untuk ritual tertentu. }\end{array}$ & $\begin{array}{l}\text { Pembentuk jalur sirkulasi dan memperjelas } \\
\text { perubahan hirarki ruang dari publik ke semi } \\
\text { publik. }\end{array}$ \\
\hline 4 & Dua guci kuno & $\begin{array}{l}\text { Merupakan peninggalan } \\
\text { Eyang Djoego. Air dari guci }\end{array}$ & $\begin{array}{l}\text { Pembentuk sifat sakral meskipun terletak pada } \\
\text { ruang yang bersifat publik. }\end{array}$ \\
\hline
\end{tabular}


tersebut dipercaya dapat

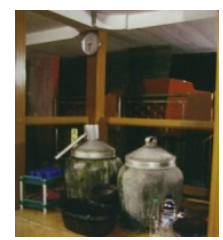

menyembuhkan penyakit.

$5 \quad$ Makam Eyang Djoego dan R.M Iman Soedjono
Merupakan tempat paling sakral pada Pesarean Gunung Kawi.
Sebagai penanda zona privat yang bersifat sakral dan memiliki aksesibilitas ruang terbatas.

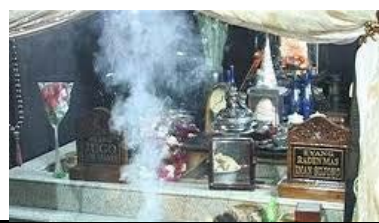

\section{Klenteng Kwan Im}

Klenteng Kwan Im merupakan tempat peribadatan peziarah yang termasuk dalam kelompok Tridharma (Buddha, Konghuchu dan Tao). Para peziarah melakukan sembayang di klenteng ini sebelum melakukan ziarah di Pendopo Agung. Untuk pelaksanaan ritual yang dilakukan pada Klenteng Kwan Im, terdapat peralatan yang mendukung proses ritual (Gambar 7).

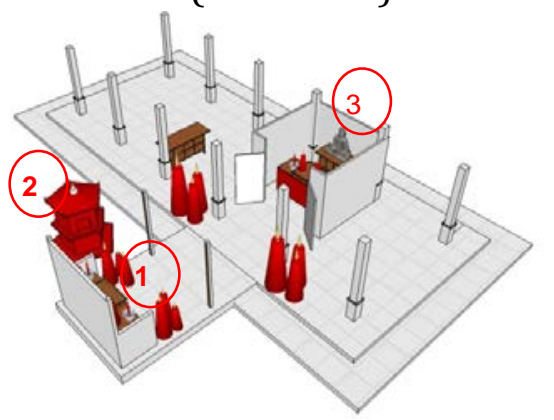

1. Altar

2. Tempat pembakaran kertas

3. Altar

Gambar 7. Atribut ruang pada Klenteng Kwan Im

Adanya atribut ruang tersebut sangat berpengaruh pada ruang ritual pada Klenteng Kwan Im. Selain itu proses pelaksanaan ritual juga dipengaruhi oleh letak atribut ruang yang ada (Tabel 2).

\section{Tabel 2. Peran Atribut Ruang pada Klenteng Kwan Im}

\begin{tabular}{|c|c|c|c|}
\hline No & Atribut Ruang & Keterangan & Peran dalam Ruang \\
\hline 1 & Altar & $\begin{array}{l}\text { Altar ini digunakan untuk } \\
\text { membakar hio dan } \\
\text { merupakan awal dari proses } \\
\text { sembayang pada Klenteng } \\
\text { Kwan Im. }\end{array}$ & $\begin{array}{l}\text { Altar ini terletak pada ruang yang bersifat semi } \\
\text { terbuka, sehingga atribut ruang tersebut } \\
\text { memperkuat identitas Klenteng dan membentuk } \\
\text { hirarki ruang berdasarkan aktivitas yang } \\
\text { dilakukan. }\end{array}$ \\
\hline 2 & $\begin{array}{l}\text { Tempat pembakaran } \\
\text { kertas }\end{array}$ & $\begin{array}{l}\text { Tempat pembakaran kertas } \\
\text { merupakan suatu atribut } \\
\text { yang khas pada suatu } \\
\text { klenteng. }\end{array}$ & $\begin{array}{l}\text { Oleh karena atribut ini merupakan salah satu ciri } \\
\text { khas klenteng dan terletak di luar ruangan maka } \\
\text { memperkuat identitas klenteng. }\end{array}$ \\
\hline 3 & Altar & $\begin{array}{l}\text { Altar utama untuk aktivitas } \\
\text { peribadatan pada Klenteng }\end{array}$ & $\begin{array}{l}\text { Adanya patung Dewi Kwan Im pada altar } \\
\text { menimbulkan kesan sakral dan membentuk zona }\end{array}$ \\
\hline
\end{tabular}




\section{Kuil Ciamsi}

Kuil Ciamsi merupakan tempat untuk melakukan ramalan nasib. Meskipun tempat tersebut kental dengan budaya yang sesuai dengan kelompok Tridharma, namun semua pengunjung dari berbagai etnis dan kepercayaan dapat mengakses tempat ini untuk melakukan ritual sesuai dengan tata cara kelompok Tridharma. Pada ruang yang digunakan untuk melakukan ritual terdapat perabot yang mendukung pelaksanaan ritual (Gambar 8). Selain mendukung pelaksanaan ritual, atribut ruang juga berperan dalam pembentukan ruang ritual (Tabel 3).

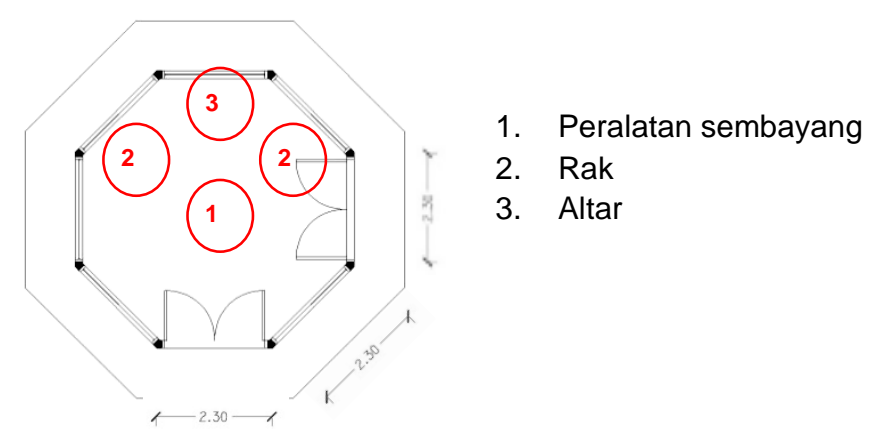

Gambar 8. Atribut Ruang pada Kuil Ciamsi

Tabel 3. Peran Atribut Ruang pada Kuil Ciamsi

\begin{tabular}{|c|c|c|c|}
\hline No & Atribut Ruang & Keterangan & Peran dalam Ruang \\
\hline 1 & Peralatan sembayang & $\begin{array}{l}\text { Terdiri atas lilin, hio, minyak } \\
\text { dan lainnya. }\end{array}$ & $\begin{array}{l}\text { Adanya peralatan sembayang memperkuat } \\
\text { identitas Kuil Ciamsi dan membatasi zona publik } \\
\text { yang bersifat profan dan zona privat yang } \\
\text { bersifat sakral. }\end{array}$ \\
\hline 2 & Rak & $\begin{array}{l}\text { Berfungsi } \begin{array}{l}\text { sebagai } \\
\text { meletakkan } \\
\text { ciamsi. }\end{array} \\
\text { ciartas }\end{array}$ & $\begin{array}{l}\text { Keberadaan rak mendukung dalam pelaksanaan } \\
\text { aktivitas pada Kuil Ciamsi. Selain itu rak } \\
\text { berfungsi sebagai pembatas antara ruang publik } \\
\text { yang dapat diakses oleh pengunjung dan ruang } \\
\text { privat yang hanya boleh diakses oleh pegawai } \\
\text { pesarean. }\end{array}$ \\
\hline 3 & Altar & $\begin{array}{l}\text { Berfungsi untuk meletakkan } \\
\text { peralatan sembayang. }\end{array}$ & $\begin{array}{l}\text { Posisi atribut ruang yang lurus dari pintu masuk } \\
\text { sehingga memudahkan pencapaian oleh para } \\
\text { pengunjung. Selain itu altar juga berfungsi } \\
\text { membentuk sifat sakral dalam ruangan dan arah } \\
\text { orientasi pada pelaksanaan ritual. }\end{array}$ \\
\hline
\end{tabular}


Seperti yang telah dijelaskan pada tabel tersebut bahwa atribut ruang juga berperan sebagai pembentuk zonasi ruang (Gambar 9). Ruang privat yang terbentuk pada Kuil Ciamsi diperuntukkan bagi para pegawai ciamsi ataupun pesarean.

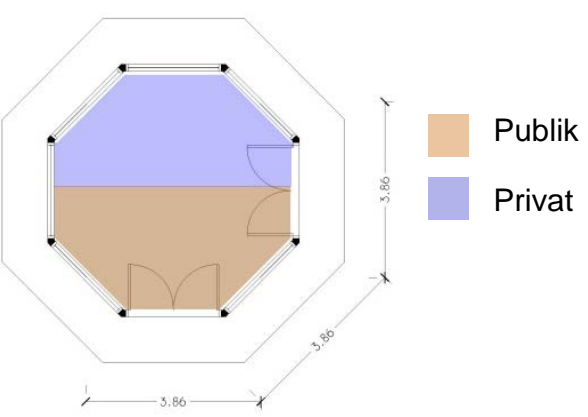

Gambar 9. Derajat Privasi Ruang Kuil Ciamsi

\section{Padepokan R.M Iman Soedjono}

Bangunan ini merupakan tempat tinggal Raden Mas Iman Soedjono ketika menetap di Desa Wonosari. Padepokan juga merupakan tempat yang disakralkan selain Pendopo Agung karena terdapat beberapa barang peninggalan Eyang Djoego dan R.M Iman Soedjono (Gambar 10). Oleh karena itulah pada tempat ini juga merupakan tempat dilaksanakannya berbagai aktivitas ritual.

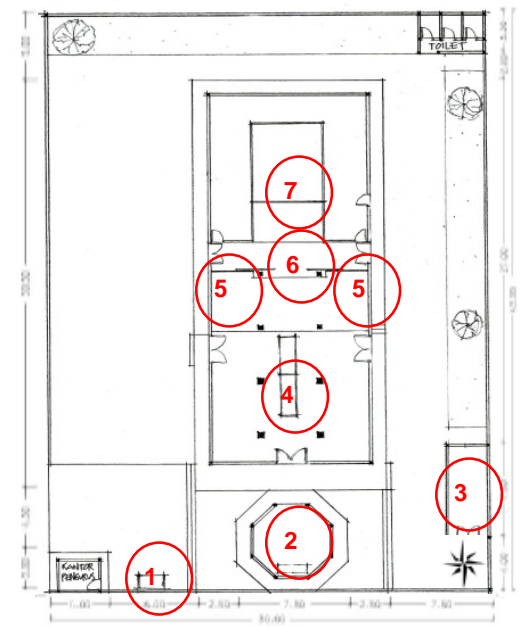

1. Air suci sumber manggis

2. Altar

3. Peralatan pertunjukan wayang kulit

4. Meja

5. Jam

6. Pintu dan kelambu

7. Keris peninggalan Eyang Djoego dan R.M Iman Soedjono

Gambar 10. Atribut Ruang pada Padepokan R.M Iman Soedjono

Beberapa atribut ruang yang terletak di dalam ruang dipengaruhi oleh ruang ritual, seperti meja, altar serta pintu dan kelambu, atau dengan kata lain bahwa atribut tersebut disediakan untuk mendukung pelaksanaan aktivitas ritual. Namun juga terdapat atribut ruang yang membentuk ruang ritual. Aktivitas ritual yang dilaksanakan muncul karena adanya atribut ruang tersebut, seperti dengan adanya air suci sumber manggis dan keris peninggalan Eyang Djoego dan R.M Iman Soedjono.

Selain sebagai pembentuk ruang ritual atribut ruang juga berfungsi memperjelas hirarki ruang. Seperti halnya pada Pendopo Agung, hirarki kesakralan ruang ditunjukkan dengan perbedaan level lantai (Gambar 11). Selain hirarki kesakralan ruang, atribut dan pembatas ruang berfungsi dalam pembagian zonasi ruang (Gambar 12). 

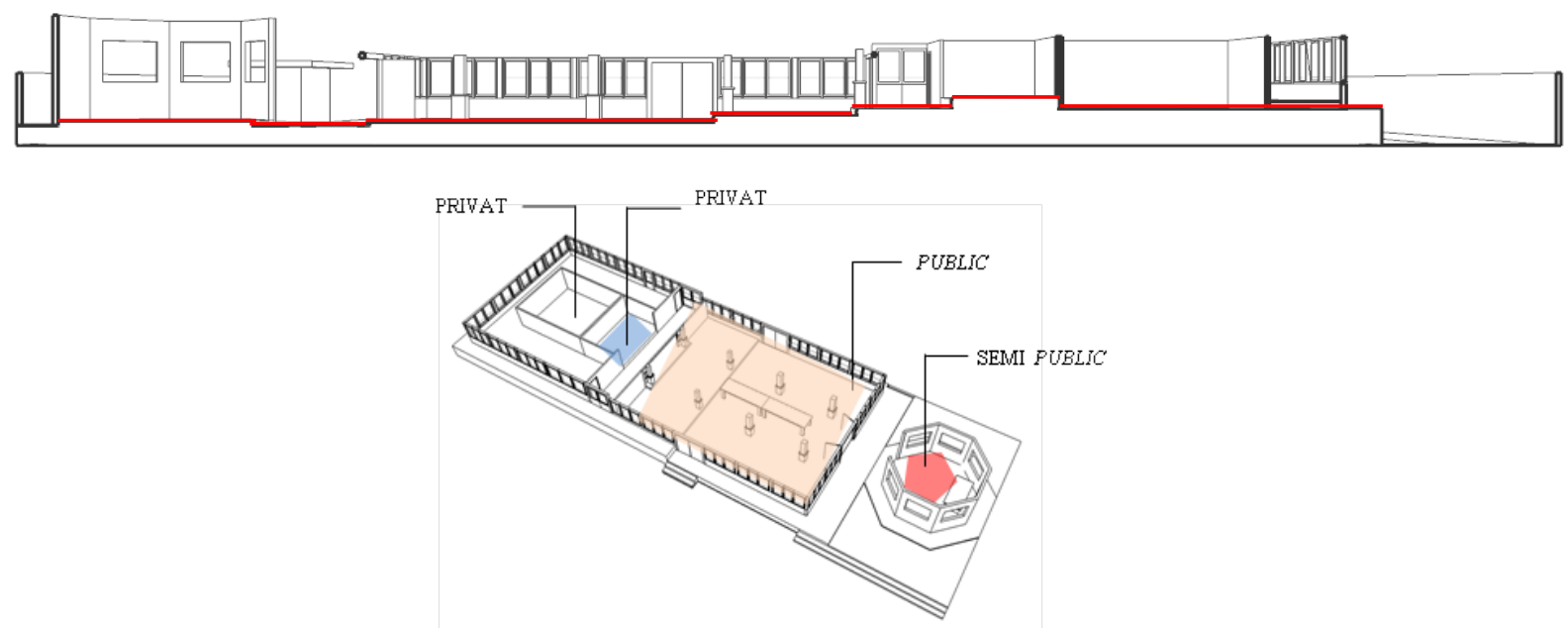

Gambar 11. Hirarki Kesakralan Ruang pada Padepokan R.M Iman Soedjono

Tabel 4. Peran Atribut Ruang pada Padepokan R.M Iman Soedjono

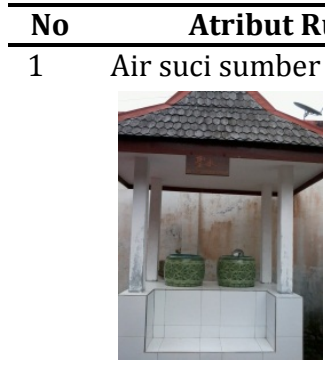

2 Altar

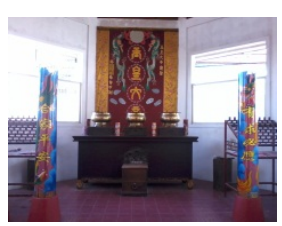

3 Peralatan pertunjukan wayang kulit

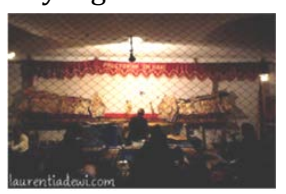

$4 \quad$ Meja

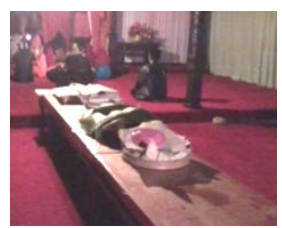

Keterangan

Air ini berasal dari sumber air bernama Sumber Manggis yang memiliki nilai historis karena pertama kali ditemukan oleh R.M Imam Soedjono.

Berfungsi untuk meletakkan peralatan sembayang.

Berfungsi untuk mengadakan pertunjukan wayang kulit yang dilaksanakan hanya saat ada permintaan.

Membantu dalam pelaksanaan ritual tertentu. Posisi dapat berubah menyesuaikan dengan kebutuhan aktivitas ritual.
Adanya peralatan sembayang memperkuat identitas Kuil Ciamsi dan membatasi zona publik yang bersifat profan dan zona privat yang bersifat sakral.

Keberadaan rak mendukung dalam pelaksanaan aktivitas pada Kuil Ciamsi. Selain itu rak berfungsi sebagai pembatas antara ruang publik yang dapat diakses oleh pengunjung dan ruang privat yang hanya boleh diakses oleh pegawai pesarean.

Posisi atribut ruang yang lurus dari pintu masuk sehingga memudahkan pencapaian oleh para pengunjung. Selain itu altar juga berfungsi membentuk sifat sakral dalam ruangan.

Oleh karena bersifat fleksibel yang menyesuaikan dengan kebutuhan aktivitas ritual maka meja berfungsi sebagai pembentuk orientasi dan ruang ritual. 


\begin{tabular}{|c|c|c|c|}
\hline 5 & Jam & $\begin{array}{l}\text { Merupakan pemberian dari } \\
\text { peziarah yang doanya telah } \\
\text { terkabul. }\end{array}$ & $\begin{array}{l}\text { Untuk menghargai pemberian para peziarah } \\
\text { maka benda ini diletakkan di zona publik, } \\
\text { sehingga dapat memperkuat zona ruang publik } \\
\text { pada ruang tengah Padepokan R.M Iman } \\
\text { Soedjono. }\end{array}$ \\
\hline 6 & Pintu dan kelambu & $\begin{array}{l}\text { Berfungsi sebagai pembatas } \\
\text { ruang yang boleh digunakan } \\
\text { pada saat-saat tertentu. }\end{array}$ & $\begin{array}{l}\text { Dengan bentuk yang sangat massif, pintu } \\
\text { berfungsi sebagai pembatas zona publik dan } \\
\text { semi publik. }\end{array}$ \\
\hline 7 & $\begin{array}{l}\text { Keris peninggalan Eyang } \\
\text { Djogo dan R.M Iman } \\
\text { Soedjno }\end{array}$ & $\begin{array}{l}\text { Merupakan benda yang } \\
\text { dikeramatkan. }\end{array}$ & $\begin{array}{l}\text { Sebagai penanda zona privat yang bersifat sakral } \\
\text { dan memiliki aksesibilitas ruang terbatas. }\end{array}$ \\
\hline
\end{tabular}

\section{Kesimpulan}

Hasil studi menunjukkan bahwa banyaknya aktivitas ritual yang ada pada Pesarean Gunung Kawi dipengaruhi oleh tempat pelaksanaan beserta atribut ruang yang ada di dalamnya. Atribut ruang dapat dihilangkan ataupun dimunculkan sehingga dalam pembentukan ruang ritual, atribut ruang bersifat fleksibel bergantung pada kebutuhan dari aktivitas ritual. Selain sebagai penanda dan pembentuk ruang ritual, atribut ruang juga berfungsi membagi ruang berdasarkan derajat privasi dan tingkat kesakralan dan membentuk kesan suatu ruang.

\section{Daftar Pustaka}

Deapati, Andi Karena. 2009. Ruang dan Ritual Kematian: Hubungan Upacara dan Arsitektur Kelompok Etnis Toraja. Depok: Universitas Indonesia. http://lontar.ui.ac.id/file?file=digital/20249524-R050941.pdf (diakses pada 2 Februari 2014)

Hall, Edward. 1966. The Hidden Dimension. New York: Anchor Books.

Koentjaraningrat. 1990. Manusia dan Kebudayaan di Indonesia. Jakarta: Djambatan. Tjahjono, Rusdi \& Santoso, J.T. 2004. Tipologi Konstruksi Tradisonal pada Cungkup Makam Prapen. Jurnal RUAS II (1): 16-25. 